Aleksandra Golinska-Zach

Patrycja Krawczyk-Szulc

Marta Wiszniewska

Ewa Nowakowska-Świrta

Dominika Świerczyńska-Machura

Diana Tymoszuk

Jolanta Walusiak-Skorupa

\title{
SENSITIZATION TO OCCUPATIONAL ALLERGENS IN HAIRDRESSING APPRENTICES DIAGNOSED ALREADY BEFORE ENTERING VOCATIONAL TRAINING
}

\author{
UCZULENIE NA ALERGENY ZAWODOWE WŚRÓD UCZNIÓW FRYZJERSKICH \\ PRZED ROZPOCZECIEM PRAKTYCZNEJ NAUKI ZAWODU
}

Nofer Institute of Occupational Medicine / Instytut Medycyny Pracy im. prof. J. Nofera, Łódź, Poland

Clinic of Occupational Diseases and Toxicology, Department of Occupational Diseases / Klinika Chorób Zawodowych i Toksykologii, Oddział Chorób Zawodowych

\begin{abstract}
Background: Hairdressers are occupationally exposed to many allergenic and irritating substances. Additionally, hairdressing apprentices are exposed to the same allergens as professional hairdressers, due to the fact that vocational training starts in the beginning of the education. This study was undertaken to investigate early occurrence of sensitization to occupational allergens in hairdressing apprentices before the onset of the vocational training. Material and Methods: Three hundred and seven hairdressing apprentices were assessed using a questionnaire and skin prick tests (SPTs) to common and occupational allergens. The level of total and serum specific immunoglobulin E (IgE) to occupational allergens was evaluated and spirometry was performed. Results: At least one skin and/or respiratory and/or conjunctival symptom was reported by $29.9 \%$ of subjects. Among subjects with at least one symptom, $28.2 \%$ of them were atopic whereas among $43.4 \%$ of them total IgE level was elevated. Atopy was found in $20 \%$ cases. In the case of one apprentice, positive SPT for paraphenylenediamine was found. Nearly $33 \%$ of apprentices had elevated total IgE level and 5 of them had specific IgE for occupational allergens. Conclusions: The study revealed that hairdressing apprentices might be sensitized to occupational allergens even before the beginning of vocational training, due to prior non-professional exposure to hairdressing agents. Furthermore, many of them report skin, respiratory and conjunctival symptoms, often connected with chronic disease diagnosis. Thus, candidates for hairdressers should be examined thoroughly before the start of the education and tests for allergy to hairdressing substances are indicated. Med Pr 2016;67(5):567-575
\end{abstract}

Key words: vocational training, hairdressers, professional exposure, apprentices, occupational allergens, hairdressing allergens

\begin{abstract}
STRESZCZENiE
Wstęp: Praca w zawodzie fryzjera związana jest z narażeniem na wiele substancji o działaniu alergizującymi drażniącym. Uczniowie fryzjerscy są narażeni na te same alergeny co fryzjerzy profesjonalni, ponieważ praktyczna nauka zawodu zaczyna się na początku nauki w szkole zawodowej. Celem badania było wykrycie uczulenia na alergeny zawodowe u uczniów fryzjerskich obecnego u nich przed rozpoczęciem praktyk zawodowych. Materiał i metody: U 307 uczniów fryzjerskich przeprowadzono badania kwestionariuszowe i spirometryczne, punktowe testy skórne (PTS) z pospolitymi aeroalergenami i alergenami zawodowymi. Oznaczono też poziom całkowitej immunoglobuliny E (IgE) i swoistych IgE dla alergenów zawodowych w surowicy krwi. Wyniki: Występowanie przynajmniej jednego objawu ze strony skóry i/lub układu oddechowego, i/lub spojówek zgłosiło 29,9\% badanych. Wśród $28,2 \% \mathrm{z}$ nich stwierdzono atopię, a u 43,4\% podwyższony poziom całkowitej IgE. W całej grupie badanej atopia występowała u 20\% uczniów, a podwyższony poziom całkowitej IgE u 32,8\%. U 1 osoby stwierdzono dodatnie wyniki PTS dla parafenylenodiaminy, a u 5 osób obecność swoistych IgE dla fryzjerskich alergenów zawodowych. Wnioski: Badanie wykazało, że uczniowie fryzjerscy mogą być uczuleni na alergeny zawodowe już przed rozpoczęciem praktycznej nauki zawodu, co jest związane $\mathrm{z}$ dużą pozazawodową ekspozycją na alergeny fryzjerskie. Ponadto wielu z nich jeszcze przed ekspozycją zawodową zgłasza dolegliwości ze strony skóry, układu oddechowego i spojówek, co jednak często wynika z wcześniej rozpoznanych chorób przewlekłych. Z tego powodu ważne jest przeprowadzanie wnikliwych badań, w tym testów alergologicznych, wśród kandydatów do szkół fryzjerskich przed rozpoczęciem przez nich nauki. Med. Pr. 2016;67(5):567-575
\end{abstract}

Słowa kluczowe: szkolenie zawodowe, fryzjerzy, narażenie zawodowe, uczniowie, alergeny zawodowe, alergeny fryzjerskie

Funding / Finansowanie: within the scope of the programme "Design of complex prophylaxis projects" (POKL/Profil/2008-2013/zadanie 3). Project manager: Prof. Jolanta Walusiak-Skorupa. 
Corresponding author / Autorka do korespondencji: Aleksandra Golińska-Zach, Nofer Institute of Occupational Medicine, Clinic of Occupational Diseases and Toxicology, Department of Occupational Diseases, św. Teresy 8, 91-348 Łódź, Poland, e-mail: golala@o2.pl

Received: April 20, 2015, accepted: March 22, 2016

\section{INTRODUCTION}

Hairdressing is one of the most common and developing service industry in Poland. According to the Polish Educational Information System (System Informacji Oświatowej - SIO) in 2004 only 14000 hairdressing apprentices were registered in Poland whereas in 2012 over 23000 young people were being trained in this profession. Hairdressers are occupationally exposed to many substances, both allergenic and irritating and the continuous development of this kind of services brings about new risks. Hairdressing apprentices are exposed to the same allergens as professional hairdressers, due to the fact that vocational training starts in the beginning of the education [1].

There are some studies indicating that apprentices exposed to some allergens at work (e.g., bakers, animal breeders, grain workers, etc.), who are thence at risk of allergic diseases, may develop health disorders very early, even during their occupational training [2-4]. However, Walusiak et al. indicates that almost $2 \%$ of examined baker apprentices were sensitized to bakers' allergens when they started the occupational training [2]. While bakers are generally exposed to high molecular weight (HMW) agents [2], hairdressers' occupational allergens are mainly low molecular weight (LMW) substances, contained in dyes, bleachers and other preparations [5].

High prevalence of hairdressing cosmetics may suggest that young people might have developed the sensitization to these allergenic agents before the vocational training starts [1,6]. Furthermore, symptoms of allergic diseases, that have been diagnosed before the onset of the apprenticeship, may deteriorate due to irritating and/or allergenic substances [7].

The study has been scheduled as a prospective one. The evaluation of apprentices has been planned to be performed on the entry to vocational training (stage 0 ), after the first year (stage I), the second year (stage II) and in the third year (stage III) of vocational training. The aim of this paper is to investigate early occurrence of sensitization to occupational allergens in the case of hairdressing apprentices before the onset of the vocational training for further follow up observations.

\section{MATERIAL AND METHODS}

\section{Study group}

The study population consists of hairdressing apprentices attending the vocational training school located in Łódź, central Poland, in the beginning of the first year of their training. The recruitment was done in the last week of the summer holidays, during the parent-teacher meetings. All first-year apprentices attending the school were invited to take part in the study (379 subjects) and were asked to deliver written informed consents to participation in the study signed both by the participants themselves and their caretakers, what was done by 321 . Upon the agreement of the management board of the school, days of examination were established and announced in the school. On these days a group of research workers from the Nofer Institute of Occupational Medicine (Łódź, Poland), comprising an occupational medicine physician, 3 laboratory workers and a nurse, came to the school and conducted the examinations. The testing had been run in the first week of the education, before the vocational training started. Eventually, 307 apprentices (81\% participation rate) entered into the study.

\section{Questionnaire}

The interview with the occupational medicine physician was the first step of every examination. The subjects were administered a questionnaire that included questions necessary to collect information about the presence of skin, respiratory, and conjunctival symptoms. The following respiratory symptoms were inquired of: cough, sneezing and/or runny nose, dyspnoea on exertion and/or dyspnoea at rest. The hairdressing apprentices were also asked about suffering from any chronic disease, taking medicines, sensitizations to common allergens and drugs, that they were aware of, and family history of allergic diseases. Finally, information about smoking habits, bleaching and dyeing hair, piercing and tattoos (temporary and permanent) was acquired.

\section{Skin prick tests}

The skin prick tests (SPTs) were performed on the volarpart of the forearm with a standard battery of common aller- 
gens (Allergopharma, Germany, and Stallergenes, France) and allergens typical of hairdressers' working environment. Common allergens included: mites (Dermatophagoides pteronyssinus, Dermatophagoides farinae), pollens (mixed trees - alder, hazel, poplar, elm, willow, birch, oak, beech, plane; mixed grass - holcus, festuca, orchard grass, rye grass, timothy grass, bluegrass; mixed weeds - sagebrush, nettle, dandelion, narrow leaf plantain), mixed moulds and feathers (of goose, duck and hen). Occupational allergens included $0.01 \%, 0.1 \%$ and $1 \%$ solutions of 1.4-paraphenylenodiamine (PPD) and $0.01 \%, 0.1 \%$ and $1 \%$ solutions of potassium peroxodisulfate. The SPTs were performed according to standardized techniques [8] and assessed after $15 \mathrm{~min}$. Positive reaction was defined as a wheal diameter equal to or greater than $3 \mathrm{~mm}$ in the absence of a reaction to the control diluents and in the presence of positive reaction to histamine [2].

\section{Pulmonary function tests}

Lung function was measured with a calibrated portable spirometer (MicroLab ML 350, Micro Medical Ltd., Great Britain). The test was performed in a sitting position and conducted by a trained operator. The manoeuvre was repeated 3 times to select the best result. The following parameters were recorded: forced vital capacity (FVC), forced expired volume in $1 \mathrm{~s}\left(\mathrm{FEV}_{1}\right)$ and the ratio of $\mathrm{FEV}_{1}$ to ventilatory capacity (VC) (Tiffeneau index).

\section{Blood sampling}

Blood samples were taken to determine total immunoglobulin E (IgE) by the Phadia method (ImmunoCap-100 System, Phadia, Sweden). Total IgE level > $100 \mathrm{kU} / \mathrm{l}$ was considered as elevated. Specific serum IgE (sIgE) was evaluated using the methods of Phadia (ImmunoCap-100 System, Phadia, Sweden) and Biomedica (HY-TEC 288 Analyzer, Hycor Biomedical GmbH, USA). The IgE antibodies specific for the following occupational allergens were registered: henna (c613, Biomedica, USA), ammonium persulfate (c604, Biomedica, USA), chrome (c609, Biomedica, USA), nickel chloride (c628, Biomedica, USA), latex (k82, Phadia, Sweden), disinfectants (pax6: chloramine, formaldehyde, glutaraldehyde, phthalane anhydride, Phadia, Sweden) and formaldehyde (k80, Phadia, Sweden). Immunoglobulin E level higher than $0.350 \mathrm{kU} / \mathrm{l}$ was regarded as positive.

\section{Diagnostic criteria}

Atopy was defined by at least one positive SPT response to common allergens [1]. The subjects were classified as nonsmokers if they had never smoked daily. Ex-smokers were those who had been smoking daily and quit smoking before the study. Smokers were those who smoked daily at the time of the study [8]. Skin diseases were recognized in subjects reporting skin symptoms (contact dermatitis, urticaria, acne symptoms, psoriasis symptoms). Recognition of respiratory disorders was based on the presence of cough, sneezing or runny nose, dyspnoea on exertion and/or dyspnoea at rest. Conjunctival symptoms were recognized in subjects reporting tearing, sore eyes, conjunctivitis. Chronic disease was defined as a non-allergic chronic disease reported by subjects, diagnosed prior to this study, who required or not required the treatment (cardiac arrhythmia, epilepsia, mental diseases, thyroid diseases, acne, psoriasis).

Three hundred and five of 307 participants did not receive any systemic or local medication. In the case of 2 subjects treatment with drugs blocking histamine $\mathrm{H} 2$ receptors could not have been stopped due to chronic diseases.

\section{Statistical analysis}

Continuous variables were presented as mean values $(\mathrm{M}) \pm$ standard deviations $(\mathrm{SD})$ and the nominal variables as numbers and percentages. All the calculations were performed with the Statistica 8 Software.

The project obtained approval from the local Bioethical Commission (No. 17/2008).

\section{RESULTS}

Final outcomes of examinations of 307 apprentices (281 girls, 26 boys) were analyzed. The mean age of the study participants was $16.29 \pm 0.52$ years old (range: $15-$ 18 years).

Characteristics of the study group, information on medical and family history as well as information on habits that may affect an atopic status are shown in the Table 1.

Ninety-two subjects (29.9\%) reported at least one skin and/or respiratory and/or conjunctival symptom, that had been appearing systematically, or at least once during the lifetime, due to specific agent. Analysis of reported symptoms is presented in the Table 2.

The most common in this group were skin symptoms (55.4\%), and the least often dyspnoea was reported (10.8\%). Thirty-seven apprentices with diagnosed chronic diseases lodged at least one symptom. Nineteen of them had an allergic disease, and 14 - non-allergic chronic disease. The relation between reported symptoms and presence of chronic disease is shown in the 
Table 1. Characteristics of the studied hairdressing apprentices Tabela 1. Charakterystyka badanych uczniów fryzjerskich

\begin{tabular}{|c|c|}
\hline $\begin{array}{l}\text { Characteristics } \\
\text { Charakterystyka }\end{array}$ & $\begin{array}{l}\text { Study group } \\
\text { Grupa badana } \\
(\mathrm{N}=307) \\
{[\mathrm{n}(\%)]}\end{array}$ \\
\hline \multicolumn{2}{|l|}{ Sex / Płeć } \\
\hline males / mężczyźni & $26(8.4)$ \\
\hline \multicolumn{2}{|l|}{ Age [years] / Wiek [w latach] } \\
\hline 18 & $9(2.9)$ \\
\hline 17 & $72(23.5)$ \\
\hline 16 & $225(73.3)$ \\
\hline current or ex-smokers / palący obecnie lub w przeszłości & $150(48.9)$ \\
\hline Family history of atopy / Wywiad rodzinny w kierunku atopii & $84(27.4)$ \\
\hline Hair bleaching or dying currently or in the past / Rozjaśnianie lub farbowanie włosów obecnie lub w przeszłości & $233(75.9)$ \\
\hline Piercing (at least 1 part of body) currently or in the past / Kolczykowanie (przynajmniej 1 części ciała) obecnie lub w przeszłości & $275(89.6)$ \\
\hline Tattoo (temporary and/or permanent) / Tatuaż (tymczasowy i/lub permanentny) & $86(28.0)$ \\
\hline Chronic diseases / Choroby przewlekłe & $50(16.3)$ \\
\hline $\begin{array}{l}\text { respiratory allergic diseases (asthma, rhinitis, seasonal rhinitis/rhinoconjunctivitis) / alergiczne choroby dróg oddechowych } \\
\text { (astma, alergiczny nieżyt nosa, pyłkowica) }\end{array}$ & $20(6.5)$ \\
\hline
\end{tabular}

Table 2. Five of the apprentices with skin symptoms had diagnosis of atopic dermatitis, 4 subjects suffered from seasonal rhinitis/rhinoconjunctivitis, and in 4 cases skin problems were reported by apprentices with diagnosed asthma and/or allergic rhinitis. Among subjects with non-allergic chronic diseases, who reported skin symptoms, 10 suffered from acne and 3 - from psoriasis.

Dyspnoea was usually connected with diagnosis of bronchial asthma or seasonal rhinitis/conjunctivitis. As far as cough and runny nose and sneezing were concerned, asthma had been diagnosed for 5 subjects, allergic rhinitis - for 6 subjects and seasonal rhinitis - for 3 subjects. Seven apprentices with conjunctival symptoms suffered from seasonal conjunctivitis, in the case of 2 of them the diagnosis of atopic conjunctivitis had been established.
Fifty-five apprentices, who reported at least one skin, respiratory and/or conjunctival symptoms, had not had diagnosed any chronic diseases. However, 28 subjects lodged symptoms typical of seasonal rhinitis/rhinoconjunctivitis (running nose and sneezing and/or conjunctivitis repeatable annually), and 8 - contact dermatitis (skin disorders in contact to specific agent). The other reported symptoms were non-characteristic.

Twenty-six of $92(28.2 \%)$ subjects with at least one symptom were atopic whereas in the case of 40 of them (43.4\%) total IgE level was elevated.

Analysis of the relation between reported symptoms and medical, family and environmental history is presented in the Table 3. The most obvious was the relation between piercing and reported symptoms over $90 \%$ of apprentices with each symptom had had 
Table 2. Symptoms reported by studied hairdressing apprentices

Tabela 2. Dolegliwości zgłaszane przez badanych uczniów fryzjerskich

\begin{tabular}{|c|c|c|c|c|}
\hline $\begin{array}{l}\text { Reported symptoms } \\
\text { Zgłaszane dolegliwości }\end{array}$ & \multicolumn{4}{|c|}{$\begin{array}{c}\text { Hairdressing apprentices } \\
\text { Uczniowie fryzjerscy } \\
{[\mathrm{n}(\%)]}\end{array}$} \\
\hline $\begin{array}{l}\text { due to metal jewellery or clothes elements / spowodowane } \\
\text { biżuterią lub metalowymi elementami ubran }\end{array}$ & $9(2.9)$ & $9(9.7)$ & - & - \\
\hline due to cosmetics / spowodowane kosmetykami & $6(1.9)$ & $6(6.5)$ & - & - \\
\hline Cough / Kaszel & $15(4.8)$ & $15(16.3)$ & $6(22.2)$ & $1(3.8)$ \\
\hline Dyspnoea / Duszność & $10(3.2)$ & $10(10.8)$ & $7(25.9)$ & $2(7.6)$ \\
\hline
\end{tabular}

at least one part of their body pierced. On the other hand, tattoos (permanent or temporary) seemed to be the least relevant factor with reference to reported skin symptoms, conjunctival symptoms, runny nose and sneezing as well as dyspnoea and atopy - to cough and conjunctival symptoms.

Table 3. Relation between symptoms reported by studied hairdressing apprentices and data from medical and family history, and lifestyle of the respondents

Tabela 3. Zależność między dolegliwościami zgłaszanymi przez badanych uczniów fryzjerskich a danymi z wywiadu medycznego i rodzinnego oraz stylem życia badanych

\begin{tabular}{|c|c|c|c|c|c|}
\hline \multirow{2}{*}{$\begin{array}{l}\text { Variable } \\
\text { Zmienna }\end{array}$} & \multicolumn{5}{|c|}{$\begin{array}{l}\text { Hairdressing apprentices reported symptoms } \\
\text { Uczniowie fryzjerscy zgłaszający dolegliwości } \\
\qquad(\mathrm{N}=92) \\
{[\%]}\end{array}$} \\
\hline & $\begin{array}{l}\text { skin symptoms } \\
\text { objawy skórne } \\
\quad(\mathrm{N}=51)\end{array}$ & $\begin{array}{c}\text { cough } \\
\text { kaszel } \\
(\mathrm{N}=15)\end{array}$ & $\begin{array}{l}\text { runny nose and } \\
\text { sneezing } \\
\text { katar i kichanie } \\
\quad(\mathrm{N}=30)\end{array}$ & $\begin{array}{l}\text { conjunctival } \\
\text { symptoms } \\
\text { objawy } \\
\text { spojówkowe } \\
(\mathrm{N}=26)\end{array}$ & $\begin{array}{l}\text { dyspnoea } \\
\text { duszność } \\
(\mathrm{N}=10)\end{array}$ \\
\hline Smoking / Palenie tytoniu & 54.9 & 53.3 & 60.0 & 46.1 & 80.0 \\
\hline $\begin{array}{l}\text { Hair bleaching or dying currently or in the past / Rozjaśnianie } \\
\text { lub farbowanie włosów obecnie lub w przeszłości }\end{array}$ & 82.3 & 60.0 & 83.3 & 80.7 & 70.0 \\
\hline $\begin{array}{l}\text { Piercing (at least } 1 \text { part of body) currently or in the past / } \\
\text { Kolczykowanie (przynajmniej } 1 \text { części ciała) obecnie } \\
\text { lub w przeszłości }\end{array}$ & 94.1 & 93.3 & 93.3 & 92.3 & 90.0 \\
\hline $\begin{array}{l}\text { Tattoo (temporary and/or permanent) / Tatuaż } \\
\text { (tymczasowy i/lub permanentny) }\end{array}$ & 11.7 & 33.3 & 30.0 & 42.3 & 30.0 \\
\hline $\begin{array}{l}\text { Positive family history of atopy / Pozytywny wywiad } \\
\text { rodzinny w kierunku atopii }\end{array}$ & 35.2 & 60.0 & 36.6 & 53.8 & 60.0 \\
\hline Atopy / Atopia & 21.5 & 20.0 & 50.0 & 42.3 & 50.0 \\
\hline $\operatorname{IgE}>100 \mathrm{kU} / \mathrm{l}$ & 45.0 & 53.3 & 60.0 & 53.8 & 40.0 \\
\hline
\end{tabular}

IgE - immunoglobulin E / immunoglobulina E. 
Table 4. Positive skin prick test results and reporting symptoms by studied hairdressing apprentices Tabela 4. Dodatnie punktowe testy skórne a zgłaszanie dolegliwości przez badanych uczniów fryzjerskich

\begin{tabular}{|c|c|c|}
\hline \multirow{2}{*}{$\begin{array}{c}\text { Variable } \\
\text { Zmienna }\end{array}$} & \multicolumn{2}{|c|}{$\begin{array}{l}\text { Hairdressing apprentices with SPT positive result } \\
\text { Uczniowie fryzjerscy z dodatnim wynikiem PTS } \\
\qquad[\mathrm{n}(\%)]\end{array}$} \\
\hline & $\begin{array}{c}\text { total } \\
\text { ogółem } \\
(\mathrm{N}=305)\end{array}$ & $\begin{array}{l}\text { reporting symptoms } \\
\text { zgłaszający dolegliwości } \\
\qquad(\mathrm{N}=92)\end{array}$ \\
\hline At least one common aeroallergen / Przynajmniej jeden powszechny aeroalergen & $61(20.0)$ & $26(28.2)$ \\
\hline \multicolumn{3}{|l|}{ Common aeroallergens / Powszechne aeroalergeny } \\
\hline grass pollens / pyłki traw & $32(10.5)$ & $6(6.5)$ \\
\hline trees pollens / pyłki drzew & $8(2.6)$ & $1(1.0)$ \\
\hline mites / roztocza & $32(10.5)$ & $7(7.6)$ \\
\hline feathers / pierze & $3(0.9)$ & 0 \\
\hline moulds / pleśnie & $9(2.9)$ & $3(3.2)$ \\
\hline weeds / chwasty & $17(5.5)$ & $1(1.0)$ \\
\hline \multicolumn{3}{|l|}{ Occupational allergens / Alergeny zawodowe } \\
\hline potassium persulfate / nadsiarczan potasu & 0 & 0 \\
\hline paraphenylenediamine / parafenylenodiamina & $1(0.3)$ & $1(1.0)$ \\
\hline
\end{tabular}

SPT - skin prick test / PTS - punktowy test skórny.

The skin prick tests were obtained from 305 apprentices. Two girls were excluded from the test due to lack of reaction to histamine. Atopy was found in 61 cases (20\%). The most often causing reaction allergens were grass pollens and mites (both 10.5\%) and the least often - feathers $(0.9 \%)$. In the case of one apprentice positive SPT for occupational allergen - paraphenylenediamine (PPD) was found (Table 4).

Blood samples were obtained from 298 subjects. Six girls refused to undergo this test due to fear of needle. In 3 cases volume of blood collected was insufficient to perform test. Ninety-eight apprentices $(32.8 \%)$ had elevated total IgE level $(>100 \mathrm{kU} / \mathrm{l})$ and 5 of them had specific IgE for occupational allergens (Table 5). Subject No. 5 was the one with positive SPT result for PPD. The mean level of total IgE for the whole group was $82.8 \pm 107 \mathrm{kU} / \mathrm{l}$. Forty of $98(40.8 \%)$ apprentices with elevated total IgE level reported at least one symptom.

Three hundred and three apprentices participated in pulmonary function test. Four girls refused to take part in this examination without any particular reason. Three hundred and two results of the test were taken into consideration, due to lack of cooperation with one subject. We did not observe any significant aberration in spirometry, even in the case of subjects with diagnosed asthma. The average percentage of FVC was 104.4 \pm 16.3 , $\mathrm{FEV}_{1}=106.1 \pm 17.5$, and $\mathrm{FEV}_{1} / \mathrm{VC}=99.1 \pm 11.4$.

\section{DISCUSSION}

Many studies on apprentices exposed to occupational allergens have been published [1,4,6,7,9-13], however, the subjects had been examined after the beginning of vocational training. Only few researchers focus on atopic status and symptoms reported by young people before starting the vocational training [2]. In our study in the case of 5 apprentices specific IgE for occupational allergens were detected, and in the case of 1 the skin prick test for paraphenylenediamine (PPD) was positive, despite the fact, that they had not started their hairdressing classes yet. Alike in bakers apprentices study of Walusiak et al., if these apprentices were examined after the beginning of their vocational training, we would probably make the assumption that they had developed their hypersensitivity during the training, and thence the incidence of sensitization attributed to occupational exposure would be overestimated [2]. In the meantime, the observed sensitization in the case of our subjects seems to be due to prior non-professional exposure to hairdressing allergens. What is even more important, sensitization to hairdressing occupational allergens is a risk factor for asthma, rhinitis and contact dermatitis, thus sensitive apprentices should be monitored exceptionally carefully $[10,11,14,15-17]$. 
Table 5. Questionnaire, skin prick test and sIgE level among the 5 hairdressing apprentices with confirmed allergy to occupational allergens

Tabela 5. Badanie ankietowe, punktowy test skórny i poziom sIgE u 5 uczniów fryzjerskich ze stwierdzonym uczuleniem na alergeny zawodowe

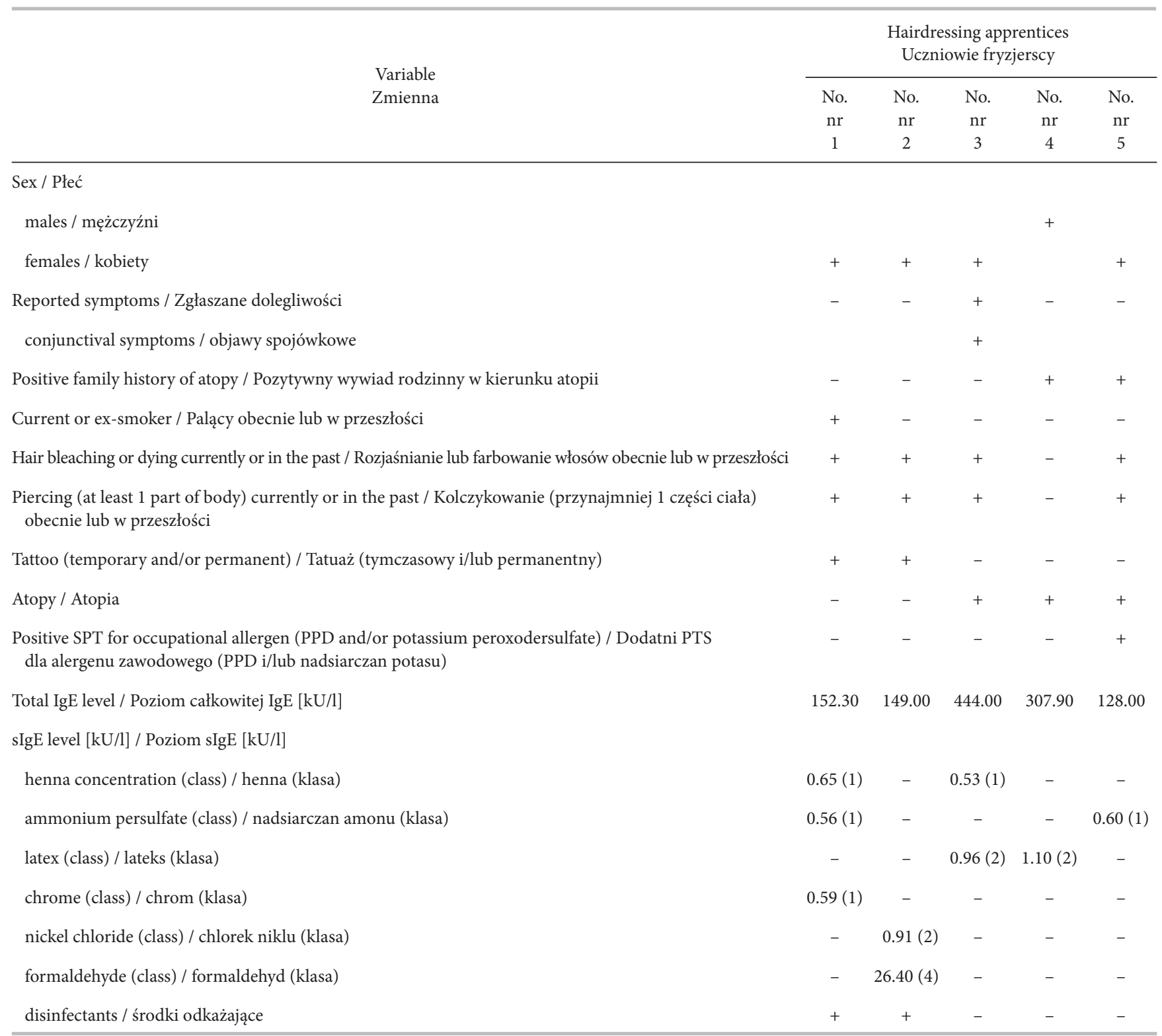

PPD - paraphenylenediamine / parafenylenodiamina, sIgE - specific immunoglobulin E / swoista immunoglobulina E.

"+" - positive result / wynik dodatni, "-" - negative result / wynik ujemny.

Other abbreviations as in Table 3 and 4 / Inne skróty jak w tabeli 3 i 4.

The specific sensitization to some allergens may be related to lifestyle habits and attitudes. Two apprentices with presence of specific IgE for agents contained in hair dyes and bleaches (PPD, ammonium persulfate) had already had their hair colored. In the whole study group, 233 subjects $(75.9 \%)$ had dyed or bleached their own hair - currently or in the past, however we expect that this percentage will increase during the next years of education. Bregnhøj et al. revealed that significantly more hairdressing apprentices had dyed their hair at the beginning of their education, the apprentices were younger at the time of their first dye use and dyed their hair more times per year than the matched control group [1]. Having a significant occupational exposure to hair dye chemicals, hairdressing apprentices may have a higher (in comparison to general population) frequency of skin [14] and respiratory [15] disorders that may develop very early, even during their apprenticeship [2-4]. 
The risk of developing severe skin allergic symptoms caused by PPD is higher if one exposed to hair dyes had also had a semi-permanent tattoo [14]. Paraphenylenediamine may be added to henna tattoos, which accelerates the dyeing process, strengthens and darkens the color and enhances the design pattern of the tattoo [16]. Several reports on exposure to temporary black henna tattoos and the development of severe allergic reactions have been published $[14,16]$. Our subject, allergic to PPD, had not had any tattoo, neither temporary nor permanent. She was instructed on complications, that the tattoo may cause to her. One of the two apprentices sensitized to henna, have already had a permanent tattoo (temporary tattoo twice in the past), however she did not report any skin disorders.

In this study nearly $90 \%$ of the subjects had had pierced at least one part of their body which usually was done in their childhood. It makes them more prone to either irritant and allergic dermatitis caused by nickel ions contained in the hairdressing tools, which may appear very early in their training, even after few months of occupational exposure [17]. Nine apprentices reported skin problems due to metal jewellery and/or clothes elements. They all had had at least one part of their body pierced. The subject, allergic to nickel, had had also ears, tongue and belly button pierced, which, we assume, had caused the sensitization. Krecisz et al. revealed that nickel was the most frequently sensitizing skin allergen in the hairdresser apprentices group. It is thought to be rather non-occupational sensitization, resulting from skin exposure to metal objects, such as jewellery, clothing accessories and particularly from piercing [17], however the release of nickel ions from nickel-containing tools exposed to thioglycolic acid in permanent wave solutions may also contribute to the high prevalence of sensitization in this professional group [18].

Twenty-seven of our subjects had diagnosis of at least one chronic allergic disease. Sensitization to common allergens was detected in $20 \%$ of our subjects, which is comparable to the results of another study of Polish apprentices that revealed frequency of atopy at the beginning of their training to be $19.2 \%$ [2]. Nevertheless, our outcome was much lower than for general population, where prevalence of atopy is estimated to be nearly $50 \%$ [19]. It may be due to healthy worker effect, however our results are scarce to confirm that theory unambiguously. Notwithstanding, there are a few researches that indicate, that healthy worker effect is present among hairdressing apprentices $[7,20]$.
Ninety-two examined apprentices reported at least one symptom, 19 (20.6\%) had diagnosis of chronic allergic disease, 26 (28.2\%) of them were atopic and 40 (43.4\%) of them had elevated total IgE level. Although researchers are consentaneous that atopy is a relevant risk factor only for these occupational allergic diseases that are caused by HMW factors $[2,21,22]$ whereas most of hairdressers' occupational allergens are LMW substances, Leno et al. revealed that the risk of leaving the profession was approximately $20 \%$ higher for hairdressers who had suffered at some point in their lives from an atopic disease [23]. It is clear that sensitive individuals cannot be debarred from vocations with high risk of allergy, due to high prevalence of atopy in general population, as well as widespread usage of hairdressing cosmetics. However, our study indicates that screening for allergy before the onset of study may be the useful method for identifying and further monitoring such subjects.

\section{CONCLUSIONS}

The study revealed that hairdressing apprentices may be sensitized to occupational allergens even before the beginning of vocational training, due to prior non-professional exposure to hairdressing agents. Furthermore, many of them report skin, respiratory and conjunctival symptoms, often connected with chronic disease diagnosis. Thus, candidates for hairdressers should be examined thoroughly before the start of the education and tests for allergy to hairdressing substances are indicated. Equally important is to educate young people about the sensitizing agents connected with their future occupation.

\section{REFERENCES}

1. Bregnhøj A, Søsted H, Menné T, Johansen JD. Exposures and reactions to allergens among hairdressing apprentices and matched controls. Contact Dermat. 2011;64:85-9, http://dx.doi.org/10.1111/j.1600-0536.2010.01843.x.

2. Walusiak J, Hanke W, Górski P, Pałczyński C. Respiratory allergy in apprentice bakers: Do occupational allergies follow the allergic march? Allergy. 2004;59:442-50, http://dx.doi.org/10.1111/j.1398-9995.2003.00418.x.

3. Dosman JA, McDuffie HH, Pahwa P. Atopic status as a factor in job decision making in grain workers. J Occup Med. 1991;33:1007-10.

4. Gautrin D, Ghezzo H, Infante-Rivard C, Malo J-L. Natural history of sensitization, symptoms and occupational diseases in apprentices exposed to laboratory animals. 
Eur Respir J. 2001;17:904-8, http://dx.doi.org/10.1183/09 031936.01.17509040.

5. Golińska-Zach A, Krawczyk-Szulc P, Walusiak-Skorupa J. [Etiology, determinants, diagnostics and prophylaxis of occupational allergic respiratory diseases in hairdressers]. Med Pr. 2011;62(5):517-26. Polish.

6. Gautrin D, Ghezzo H, Infante-Rivard C, Malo J-L. Incidence and determinants of IgE-mediated sensitization in apprentices. A prospective study. Am J Respir Crit Care Med. 2000;162(4);1222-8, http://dx.doi.org/10.1164/ajrccm.162.4.2001023.

7. Iwatsubo Y, Matrat M, Brochard P, Ameille J, Choudat $\mathrm{D}$, Conso F, et al. Healthy worker effect and changes in respiratory symptoms and lung function in hairdressing apprentices. Occup Environ Med. 2003;60: 831-40, http://dx.doi.org/10.1136/oem.60.11.831.

8. Quirce S, Lemiere C, de Blay F, del Pozo V, van Wijk RG, Maestrelli $P$, et al. Noninvasive methods for assessment of airway inflammation in occupational settings. Allergy. 2010;65:445-58, http://dx.doi.org/10.1111/j.13989995.2009.02274.x.

9. Hollund BE, Moen BE, Egeland GM, Florvaag E, Omenaas E. Occupational exposure to hairdressing chemicals and immonoglobin E synthesis. Scand J Work Environ Health. 2002;28(4):264-69, http://dx.doi.org/10.5271/ sjweh.674.

10. Tossa P, Bohadana A, Demange V, Wild P, Michaely J-P, Hannhart B, et al. Early markers of airways inflammation and occupational asthma: Rationale, study design and follow-up rates among bakery, pastry and hairdressing apprentices. BMC Public Health. 2009;9(113), http:// dx.doi.org/10.1186/1471-2458-9-113.

11. Remen T, Acouetey D-S, Paris C, Hannhart B, Poussel M, Chenuel B, et al. Early incidence of occupational asth$\mathrm{ma}$ is not accelerated by atopy in the bakery/pastry and hairdressing sectors. Int J Tuberc Lung Dis. 2013;17(7): 973-81, http://dx.doi.org/10.5588/ijtld.12.0864.

12. Archambault S, Malo J-L, Infante-Rivard C, Ghezzo H, Gautrin D. Incidence of sensitization, symptoms, and probable occupational rhinoconjunctivitis and asthma in apprentices starting exposure to latex. J Allergy Clin Immunol. 2001;107(5):921-3, http://dx.doi.org/10.1067/ mai.2001.114116

13. Manso E, Malo J-L, Infante-Rivard C, Ghezzo H, Magnan M, L'Archeveque J, et al. Individual characteristics and quitting in apprentices exposed to high-molecular-weight agents. Am J Respir Crit Care Med. 2000;161(5):1508-12, http://dx.doi.org/10.1164/ajrccm.161.5.9906113.

14. Hansen HS, Johansen JD, Thyssen JP, Linneberg A, Søsted $\mathrm{H}$. Personal use of hair dyes and temporary black tattoos in Copenhagen hairdresses. Ann Ocup Hyg. 2010;54(4): 453-8, http://dx.doi.org/10.1093/annhyg/mep096.

15. Moscato G, Pignatti P, Yacoub M-R, Romano C, Spezia S, Perfetti L. Occupational asthma and occupational rhinitits in hairdressers. Chest. 2005;128(5):3590-8, http:// dx.doi.org/10.1378/chest.128.5.3590.

16. Brancaccio RR, Brown LH, Chang YT, Fogelman JP, Mafong EA, Cohen DE. Identification and quantification of para-phenylenediamine in a temporary black henna tattoo. Am J Contact Dermat. 2002;13:15-8, http://dx.doi. org/10.1053/ajcd.2002.30466.

17. Krecisz B, Kiec-Swierczynska M, Chomiczewska D. Dermatological screening and results of patch testing among Polish apprentice hairdressers. Contact Dermatitis. 2011;64:90-5, http://dx.doi.org/10.1111/j.16000536.2010.01844.x.

18. O'Connell RL, White IR, McFadden JP, White JML. Hairdressers with dermatitis should always be patch tested regardless of atopy status. Contact Dermatitis. 2010;62: 177-81, http://dx.doi.org/10.1111/j.1600-0536.2009.01696.x.

19. Walusiak J, Pałczyński C. [Bronchial asthma in rural environment]. Med Pr. 2003;54(1):59-66. Polish.

20. Bregnhøj A, Søsted H, Menne T, Johansen JD. Healthy worker effect in hairdressing apprentices. Contact Dermatitis. 2011;64:80-4, http://dx.doi.org/10.1111/j.16000536.2010.01831.x.

21. Martinez RO, Shams KA, Figueroa EA, Carmona MJC, Iturii JBG, Montes II, et al. Guidelines for occupational asthma. Arch Bronconeumol. 2006;42(9):457-74, http:// dx.doi.org/10.1016/S1579-2129(06)60569-7.

22. Chan-Yeung M, Malo JL. Aetiological agents in occupational asthma. Eur Respir J. 1994;7:346-71, http://dx.doi. org/10.1183/09031936.94.07020346.

23. Leino T, Tuomi K, Paakkulainen H, Klockars M. Health reasons for leaving the profession as determined among Finnish hairdressers in 1980-1995. Int Arch Occup Environ Health. 1999;72:56-9, http://dx.doi.org/10.1007/ s004200050335.

This work is available in Open Access model and licensed under a Creative Commons Attribution-NonCommercial 3.0 Poland License / Ten utwór jest dostępny w modelu open access na licencji Creative Commons Uznanie autorstwa - Użycie niekomercyjne 3.0 Polska - http://creativecommons.org/ licenses/by-nc/3.0/pl/deed.en. 